\title{
Critical Review - Impact of Differential Substitution of Organics for in Organics on Growth, Yield, Quality, Economics and Soil Properties of Cole Crop (Brassica oleracea var gonylodes $\mathbf{L}$.
}

\author{
M. Banotra*, B.C. Sharma, A. Kumar, A. Samanta, B. Nandan, \\ I.A. Shah, A. Verma, R. Kumar and T. Namgial \\ Department of Agronomy, Sher-e-Kashmir University of Agricultural Sciences \\ and Technology Jammu, J\&K, 180009, India \\ *Corresponding author
}

\begin{tabular}{l} 
K e y w or d s \\
$\begin{array}{l}\text { Growth, Knol-khol, } \\
\text { Quality and Yield. }\end{array}$ \\
\hline Article Info \\
\hline $\begin{array}{l}\text { Accepted: } \\
\text { 24 September } 2017 \\
\text { Available Online: } \\
10 \text { November } 2017\end{array}$ \\
\hline
\end{tabular}

Keywords

Growth, Knol-khol, Quality and Yield.

Aicle Info

Accepted:

Available Online:

10 November 2017
A B S T R A C T

Cole crop are the important vegetable crops because of its nutritional value and wide spread production. However, there are many problems in its cultivation. Balanced nutrition through integrated nutrient management has tremendous scope for increasing its production. In the area of where, fertilizers use by the resource constrained farmers are limited and nutrient deficiencies prominent, there is a strong need for adoption of proper nutrient management strategies. Modern nutrient management strategy has shifted its focus towards concept of sustainability and eco friendliness. Complimentary use of chemical fertilizer and organic manure has assumed great importance in vegetable crop as it increases growth, yield and quality of the Cole crop.

\section{Introduction}

India is rich in biodiversity of vegetables. Vegetables have been vividly described in Indian scriptures like "Vedas" and "Ramayana". Vegetables are the important constituents of Indian Agriculture and nutritional security due to their short duration, high yield, nutritional richness, economic viability and ability to generate on-farm and off-farm employment. The cultivation of vegetable crop is proving boon to small and marginal farmers of the country and especially helping the farmers in fetching remunerative prices during the off season.
Vegetables have a proper fitment in all the cropping system viz., mixed, sequential, companion and intercropping resulting in high cropping intensity and therefore, higher income per unit area. The demand for vegetables is now a days on the rise due to increasing population, changing food habits, realization of high nutritional value of the crops and greater emphasis on value addition and export in India as well as in entire world. Cole crops are the important cool season vegetable crops. The word "Cole" is a variation of Latin word which means "Stem". 
Initially these crops were confined to Europe and other temperate region but after the Second World War, their cultivation has spread to tropics as well. All the members of this group has originated primarily from the common ancestor wild cabbage (Brassica oleracea var oleracea) and are fully cross compatible with each other. All the Cole crops are cross pollinated crops. Among the different Cole crops Knol-khol (Brassica oleracea var gonylodes L.) is the important fast growing, short duration, Cole crop and is originated from the coastal countries of Mediterranean region (Choudhary, 1967). It has been under cultivation by Romans since 600 B.C. (Bose, 1986). In India, cultivation, of knol-khol is popular in west Bengal and some parts of South India. Moreover, knolkhol is a vegetable crop of prime importance in the traditional food habit of Jammu and Kashmir. The knol-knol is also known as 'Khol rabi' or 'German turnip'. It is known by other names in India, like 'Navalkol' and 'Ganth Gobi'. Knol-khol is a stout, round tuberous vegetable. The fleshy edible portion is an enlargement of stem, which develops entirely above ground and is used as a vegetable. It is characterized by the formation of knob (tuber) which arises from the thickening of the stem tissue above the cotyledons. The fleshy turnip like enlargement of the stem develops entirely above the ground. The swollen stem store edible food material specially starch and sugars. When consumed as raw it gives sweetish taste with slight aroma. The stem develops entirely above ground, which is edible and very delicate in flavour and texture (Singh, 1989).It is regarded as important functional food due to its high nutritional value. Knol-khol contain protein $1.1 \mathrm{~g}$, Calcium $20 \mathrm{mg}$ and other minerals $0.7 \mathrm{mg}$ per $100 \mathrm{~g}$ of edible portion. Knol-khol also gain popularity due to high ascorbic acid (Vitamin C), and potassium content combined with high dietary fibre and low amount of lipid content (Cosic et al., 2013). It also contains thiamine, riboflavin, nicotinic acid and ascorbic acid (Choudhary, 1967). In the past decades, the cultivation of knol-khol increased after the discovery of the presence of glucosinolates. This compound has strong anti-carcinogenic properties (Johnson 2002). They are also important source for anticancer "nutraceutical" compounds, fibres (including pectin and cellulose) and phenolics (Harbaum et al., 2007). Higher amounts of dietary fibres are helpful in controlling body weight and can be supplied only from vegetables with knol-khol like texture. (Terry et al., 2001).The knob is generally used as cooked vegetable. It is also utilized for making salad and pickles. Now, a days it is gaining popularity in big cities and small towns as well. Knol-khol can be grown from seeds, but frequently it is cultivated from transplants, especially for early market supply.

In the last few decades, production of vegetable crops has been enhanced manifolds by the excessive use of chemical fertilizers and pesticides (Sharma et al., 2008). The extensive use of chemical fertilizers to augment plant production is a risky proposition. Without proper fertilization practices, yields obtained from agriculture are often at the cost of soil health but the use of chemical fertilizers and chemical pesticides not only increase the cost of production but also reduce soil fertility. The toxic residues in the agriculture crops are alarming signals amongst the health cautious buyers. The uses of chemical fertilizers are also associated with health hazardous problems.

Like other vegetable crops of the family, knol-khol is a heavy feeder of mineral elements, it removes large amount of macronutrients from the soil. Heavy manuring has been recommended for getting good yield of knol-khol. Nutrient management is the key 
factor, which influences the productivity and quality of any crop but it is fact that the soil health deteriorates due to continuous use of chemical fertilizers (Savic, 2012).

The integrated nutrient management paves the way to overcome these problems, which involves the conjunctive use of chemical fertilizers and organic manures to sustain crop production as well as maintenance of soil health (Nanjappa et al., 2001). Systemic approach to nutrient management by tapping all the possible sources of organic and inorganic in a judicious manner to maintain soil fertility and crop productivity is the essence of integrated nutrient management (INM). The use of organic manures to meet the nutrient requirement of the crop would be an inevitable practice in the years to come for the sustainable agriculture. Organic manures are considered helpful in improving the physical and nutritional status of the soil and also enhance the activity of soil micro flora. They also add considerable amount of major nutrients in the soil besides improving the soil properties. Further, decomposition of organics in the soil leads to different types of biological reactions which are helpful in preventing various disease causing pathogens (Ramesh et al., 2010).

Vermicompost and Farm yard manure are the most commonly used organic manures for vegetable production. Vermicompost is a product of a non-thermophilic biodegradation of organic materials through interactions with between earth worms and microorganism (Sallaku et al., 2009). Some of the commonly used earth worms include Eisenai foetida, Lumbricus rubellus, Amyanthes diffrigens and Eudrillus engineac (Nagavalemma et al., 2004). These earthworms improve the soil physical, chemical and biological conditions for plant growth and nutrient uptake. The accelerated decomposition of plant litter and organic matter by these organisms improve soil fertility by releasing mineral elements in the forms that are available for uptake by plants (Curry, 1987). Vermicompost are the materials characterized by high porosity, aeration, drainage, water holding capacity and microbial activity. Vermicompost is made up primarily of $\mathrm{C}, \mathrm{H}$ and $\mathrm{O}$ and contain nutrients such as $\mathrm{NO}_{3}, \mathrm{PO}_{4}, \mathrm{Ca}, \mathrm{K}, \mathrm{Mg}$ and $\mathrm{S}$ which exhibits similar effects on plant growth and yield as inorganic fertilizer applied to soil (Singh et al., 2008). Similarly Vermicompost contains a high proportion of humic substances (that is humic acids, fulvic acids and humin) which provides numerous sites for chemical reaction; microbial components known to enhance plant growth and disease suppression through the activities of bacteria (Bacillus), Yeasts (Sporobolomyces and Cryptococcus) and fungi (Trichoderma), as well as chemical antagonists such as phenols and amino acids. (Nagavalemma et al., 2004).Vermicompost also contain growth regulators, vitamins, micronutrients increases the availability of plant nutrients resulting in increased growth, higher yield and better quality produce (Atiyeh et al., 2002).

\section{Effect of differential substitution of nutrients through organics on growth of knol-khol}

Bhanushalini et al., (2002) conducted experiment on sandy clay loam soil of Dharwad to study the effect of integrated nutrient management on yield of knol-khol and observed that the significantly highest plant height $(15.45 \mathrm{~cm})$, number of leaves per plant (18.75) and dry weight /plant (33.46 g) was recorded with treatment $50 \%$ N (Urea) $+50 \% \mathrm{~N}$ (VC) which was found statistically at par with treatment $50 \% \mathrm{~N}$ (Urea)+50\% N (Fym) whereas significantly lowest value of plant height $(10.44 \mathrm{~cm})$, number of leaves /plant (14.25) and dry weight /plant (27.32 g) was recorded with RDF (150:100:125 kg/ha). Kanwar and 
Paliyal (2005) conducted field experiment at on sandy loam soil Research Farm of CSKHPKV, Dhaulakuan (Sirmaur) for two years to study the effect of integrated nutrient management on growth and yield of cabbage (Brassica oleracea var. Capitata L.) and observed that the average plant height for both the years was recorded highest with treatment $\mathrm{VC}+100 \% \mathrm{NPK}$ followed $\mathrm{VC}+50$ $\%$ NPK whereas the lowest plant height was recorded with the treatment Fym $+50 \%$ NPK. Singh et al., (2009) conducted field experiment at MES, N.D university of Agriculture and Technology, Kumarganj, Faizabad during two consecutive years to study the influence of integrated nutrient management on growth, yield and economics of (Brassica oleracea L. Var. Botrytis) and assessed that significantly highest plant height, number of leaves and plant spread $(\mathrm{cm})$ of Cole crop for both the years was recorded with the treatment Fym @20 t/ha +NPK@ 120:60:60kg/ha which was found statistically at par with the treatment VM @3 t/ha+ NPK@120@120:60:60 kg/ha whereas lowest plant height was recorded with the treatment Fym @20 t/ha+ NPK @ 120:60:60 $\mathrm{kg} / \mathrm{ha}$. Padamwar and Dakore et al., (2010) in their experiment observed that the significantly highest dry matter accumulation (\%) $8.49 \mathrm{~g} / 100 \mathrm{~g}$ in knol-khol was recorded with treatment Vermicompost @ 11.3 t/ha whereas treatment Fym @ 11.3 t/ha recorded dry matter accumulation of $8.03 \mathrm{t} / \mathrm{ha}$. Dalal et al., (2010) conducted field experiment to study the effect of organic and inorganic sources of nitrogen on growth and yield of Cole crop (Brassica oleracea var. capitata $\mathrm{L}$.) and observed that significantly highest plant height $(\mathrm{cm})$, plant spread $\left(\mathrm{cm}^{2}\right)$ and number of leaves/plant was recorded with the treatment $50 \% \mathrm{~N}$ (urea) $+50 \% \quad \mathrm{~N} \quad$ (VC) whereas significantly lowest plant height and lowest number of leaves were recorded with treatment $100 \% \quad \mathrm{~N} \quad$ (FYM) whereas significantly lowest plant spread was recorded with the treatment $25 \% \mathrm{~N}($ Urea $)+75 \% \mathrm{~N}$ (FYM).Gill et al., (2011) conducted field experiment at PAU, Ludhiana to study the yield and quality traits of Cole crop (Brassica oleracea var capitata $L$.) and observed nonsignificant difference in plant height among the treatments RDF NPK @ 125:60:60 kg/ha and Fym@40 t/ha. Kumar et al., (2013) conducted a field experiment on acidic soil $\left(\mathrm{p}^{\mathrm{H}}\right.$ 5.9) at Birsa Agriculture university, Kanke Ranchi (Jharkhand) to study the effect of integrated nutrient management on growth and yield of Cole crop (Brassica oleracea var italica) and observed that highest plant height, number of leaves and plant spread $(\mathrm{cm})$ was recorded with treatment NPK 200:100:100 kg NPK whereas significantly lowest plant height was recorded with treatment $(12.5 \mathrm{~kg}$ $\mathrm{N}$ through Vermicompost +37.5:25:25 kg NPK/ha through inorganic), lowest number of leaves were recorded with treatment $(25 \mathrm{~kg} \mathrm{~N}$ through Vermicompost +75:50:50 kg NPK/ha through inorganic) and significantly lowest plant spread was recorded with treatment $(12.5 \mathrm{~kg} \mathrm{~N}$ through FYM+37.5:25:25 kg NPK/ha through inorganic). Kumar et al., (2013) conducted experiment at Horticulture Research Farm of Gochar Mahavidhyalaya, Rampur Mahiharan (Uttar Pradesh) to study the influence of integrated nutrient management on growth and yield of Cole crop (Brassica oleracea var botrytis L.) and observed that significantly highest average plant height, number of leaves per plant and spread of plant was recorded with the treatment 1/2 NPK + Vermicompost @ 2.5 tonnes/ha whereas significantly lowest value of average plant height, number of leaves per plant and spread of plant of Cole crop was recorded with the treatment recommended dose of NPK /ha (120 kg:80 kg:60 kg/ha). Chatterjee et al., (2014) conducted experiment on the sandy clay loam soil of West Bengal to study the effect of organic amendments influencing growth, head yield and nitrogen use efficiency in Cole crop 
(Brassica oleracea var capitata) and assessed that the significantly highest plant height of Cole crop was recorded with the treatment $75 \% \mathrm{RDF}+5 \mathrm{Mt} / \mathrm{ha}$ Vermicompost whereas significantly lowest plant height of Cole crop was recorded with the treatment $100 \% \mathrm{RDF}$ (150N:80P:75 K kg/ha). Shree et al., (2014) conducted field experiment at Bihar Agricultural College Sobour, to study the effect of integrated nutrient management on yield and quality of Cole crop (Brassica oleracea var Botrytis L.) and revealed that significantly highest plant height, plant spread and number of leaves of Cole crops was recorded with treatment recommended dose of N:P:K 120:80:80kg/ha whereas values of all these parameters were recorded with treatment 1/2 NPK+ Vermicompost @4 t/ha. Chaudhary et al., (2015) conducted field experiment at well-drained soil, loamy sand soil of Anand agricultural university to assess the effect of integrated nutrient management on growth of Cole crop (Brassica oleracea var. Capitata) and observed that among the different treatments significantly highest plant height of Cole crop was recorded with the treatment $100 \%$ RDN +Vermicompost @10 t/ha which was found statistically at par with the treatment $100 \%$ RDN + FYM @20 t/ha in plant height whereas lowest plant height was recorded with the treatment $75 \% \mathrm{RDN}+$ FYM@10 t/ha and 75 \% $\quad$ RDN+ Vermicompost @5 t/ha. Non-significant difference in number of leaves/plant was recorded among the different treatments. Srichandan et al., (2015) conducted field experiment at university of Agriculture and technology, Bhubaneswar for two years to study the effect of inorganic and organic nutrients on growth, yield and economics of Cole crop (Brassica oleracea var. Italica) and revealed that among the different treatments significantly highest plant height of Cole crop was recorded with the treatment 100\% $\mathrm{NPK}+50 \% \mathrm{FYM}+50 \%$ VC which was found statistically at par with $100 \% \mathrm{NPK}+100 \% \mathrm{VC}$ whereas significantly lowest plant height of Cole crop was recorded with the treatment $100 \%$ NPK. Tekasangla et al., (2015) conducted field experiment at sandy loam soil of Experimental Farm of SASRD, Medziphema campus, Nagaland and observed that among the different treatments significantly highest plant height, number of leaves and plant spread was recorded with the treatment 100\% NPK (120:60 :60 $\mathrm{kg} / \mathrm{ha})$ which was found statistically at par with the treatment 50\% NPK +50\% FYM whereas significantly lowest plant height, number of leaves and plant spread was recorded with the treatment Vermicompost @10t/ha.Kumar et al., (2017) conducted experiment at experimental farm of Dr Y S Par mar University of Horticulture and Forestry, Nauni Solan, Himachal Pradesh to study the comparative performance of organic and inorganic fertilizers on plant growth, head yield of Cole crop (Brassica Oleracea var Italica) and observed that among the different treatments significantly highest plant height and number of leaves /plant was recorded with the treatment RDF (50\%)+ FYM $(25 \%)+\mathrm{VC}(25 \%)$ which was found statistically at par with the treatment FYM $(50 \%)+\mathrm{VC}(50 \%)$ whereas significantly lowest plant height and number of leaves /plant was recorded with the treatment FYM (20 t/ha). Kumar et al., (2017) conducted field experiment at Main Agriculture Research Station, University of Agriculture and Sciences, Dharwad to assess the effect of integrated nutrient management on Cole crop (Brassica oleracea var. italica L.) observed significant difference in plant height, and number of leaves per plant whereas nonsignificant difference was recorded for plant spread $\left(\mathrm{cm}^{2}\right)$.Significantly highest plant height of the Cole crop was recorded with the treatment $100 \%$ RDF of $150 \mathrm{~N}$ : 100P: $125 \mathrm{Kkg} / \mathrm{ha}+\mathrm{Fym} @ 25 \mathrm{t} / \mathrm{ha}$ which was found statistically at par with the treatment $75 \% \mathrm{RDF}+\mathrm{FYM}$ and $\mathrm{VC}(1: 1)$ equivalent to 
$25 \%$ RDN whereas highest number of leaves per plant was recorded with the treatment $75 \% \mathrm{RDF}+\mathrm{VC}$ equivalent to $25 \% \mathrm{RDN}$ which was found statistically at par with the treatment $100 \%$ RDF of $150 \mathrm{~N}: 100 \mathrm{P}: 125 \mathrm{~K}$ $\mathrm{kg} / \mathrm{ha}+\mathrm{Fym} @ 25$ t/ha whereas significantly lowest plant height was recorded with the treatment $75 \%$ RDF + FYM equivalent to $25 \%$ $\mathrm{RDN}$ and lowest number of leaves of Cole crop was recorded with the treatment $50 \%$ $\mathrm{RDF}+\mathrm{FYM}$ equivalent to $25 \% \mathrm{RDN}$. Ram et al., (2017) conducted field experiment at experimental farm of the Department of Vegetable Science, Dr Y S Parmar University of Horticulture and Forestry, Nauni, Solan to study the effect of organic, inorganic on growth and yield of Cole crop ((Brassica oleracea var capitata)and observed that among the different treatments significantly highest plant height $(\mathrm{cm})$ and plant spread (cm) of Cole crop was recorded with the treatment (RDF $125 \quad \mathrm{~N}: 110 \mathrm{P}: 50 \mathrm{~K}$ $\mathrm{kg} / \mathrm{ha}$ +FYM 20t/ha which was found statistically at par with the plant height and plant spread recorded with the treatment $75 \% \mathrm{NP}+\mathrm{VC} @ 2.5$ t/ha whereas significantly lowest plant height and plant spread was recorded with the treatment $50 \% \mathrm{NP}+\mathrm{VC} @ 2.5 \mathrm{t} / \mathrm{ha}$.

Effect of differential substitution of nutrients through organics on yield and yield attributes of knol-khol

Experiment results of Bhanu shalini et al., (2002) revealed a significant increase in knolkhol yield with the integrated nitrogen management and observed that the highest knol-khol yield (35.86 t/ha) was recorded with the treatment $50 \% \mathrm{~N}$ (urea) $+50 \% \mathrm{~N}$ (VC) and the lowest yield was recorded with RDF (150:100:125 kg/ha). Kanwar and Paliyal (2005) reported that the highest average Cole crop (Brassica oleracea var capitata) yield was recorded with the treatment VC @ 25 t/ha +100 \% NPK whereas lowest average yield was recorded with the treatment FYM @25 /ha. Kumar et al., (2008) conducted experiment at silty clay soil during 2006-07 at Vegetable experimental Farm, Regional experimental Research Station, Rajouri to assess the effect of integrated nutrient management practices in knol-khol (Brassica oleracea var gongyloides) growing under Intermediate zone of Jammu and revealed that significantly highest knob weight (222.5g/plant) and yield (45.5 t/ha) of knol-khol was recorded with the treatment FYM@20 t/ha +50\% NPK whereas significantly lowest knob weight (111.0 $\mathrm{g} /$ plant) and yield (20.8 t/ha) of knol-khol was recorded with treatment $100 \%$ NPK(NPK:100:50:50 kg/ha).

Chaurasia et al., (2009) conducted field experiments at research farm of IIVR, Varanasi to study the effect of integrated nutrient management and spacing on yield, quality and economics of Broccoli (Brassica oleracea var.italica) and observed that significantly highest yield of Cole crop was recorded with the treatment NPK(50\%)+Fym@10t/ha whereas significantly lowest yield of Cole crop was recorded with the treatment Fym @ 20t/ha.Singh et al., (2009) while studying the effect of integrated nutrient management on the growth, yield and economics of (Brassica Oleracea L. Var. Botrytis) observed that significantly highest yield of Cole crops for both the years was recorded with the treatment Fym @20 t/ha +NPK $50 \%$ RDF (RDF- NPK: 120:60:60kg/ha) whereas the lowest yield was recorded with the treatment Fym@20t/ha+ NPK @ 120:60:60 kg/ha. Gosh et al., (2009) conducted field experiment at District Bankura in red and lateritic belt of West Bengal to study the effect of Vermicompost on growth and yield of Cole crop (Brassica oleracea L. Var Capitata) and observed that among the different treatments the highest yield (t/ha) was recorded with the 
treatment $50 \% \mathrm{VC}+50 \%$ NPK followed by $100 \%$ NPK and $25 \%$ VC $+75 \%$ NPK.Dalal et al., (2010) reported that significantly highest Cole crop (Brassica oleracea var capitata $L$.) yield (q/ha) was recorded with the treatment $50 \% \mathrm{~N}$ (urea) $+50 \% \mathrm{~N}$ (VC) which was found statistically at par with the yield (q/ha) recorded with the treatment $75 \%$ $\mathrm{N}$ (urea) $+25 \% \mathrm{~N}$ (VC) whereas significantly lowest yield $(\mathrm{g} / \mathrm{ha})$ was recorded with the treatment 100\% FYM. Gill et al., (2011) conducted field experiment at Krishi Vigyan Kendra, Punjab Agricultural University, Ludhiana observed non-significant difference in yield of Cole crop (Brassica oleracea var capaitata L.) among the treatments recommended NPK @125:60:60 kg/ha and Fym @ 40 t/ha. Patel et al., (2011) conducted field experiment at Agronomy Farm of Anand agricultural university, Gujarat to study the influence of integrated nutrient management on yield of Cole crop (Brassica oleracea var. Botrytis L.) under middle Gujarat and observed that significantly highest Cole crop yield was recorded with the treatment VC @ 4 t/ha were as significantly lowest yield of Cole crop was recorded with the treatment Fym @ 20 t/ha. Chatterjee et al., (2012) conducted field experiment at Instructional Farm of UBKV, Pundibari, West Bengal and revealed that significantly highest yield of Cole crop (Brassica Oleracea L. Var Capitata) was recorded with the treatment $75 \% \mathrm{RDF}+5$ tonnes VC/ha which was found statistically at par with $75 \%$ RDF +16 tonnes Fym/ha whereas significantly lowest Cole crop yield was recorded with the treatment $100 \%$ RDF(150 N:80N:75 P kg/ha).

Devi and Singh (2012) conducted field experiment at the Manipur university campus to study the yield response of Cole crop (Brassica oleracea var. capitata) to varying levels of chemical fertilizer and Vermicompost and observed non-significant difference in the yield of Cole crop. The highest Cole crop yield was recorded with the treatment (NPK@70:70:70kg/ha+VM@2t/ha) followed by NPK@35:35:35kg/h a+VM@ $3 \mathrm{t} /$ ha whereas numerically the lowest yield was recorded with the treatment NPK@ 105:105:105kg/ha+VM@ 1t/ha.Sharma et al., (2012) conducted field experiment at the experimental farm of SKUAST-J to assess the response of vegetable crops to use of integrated nutrient management practices and observed that significantly highest knob weight along with leaves of knol-khol (522.93 g) was recorded with treatment NPK @ 100:50:40 kg/ha which was found statistically at par with knob weight along with leaves of the treatment NPK @ $(75: 50: 40) \quad \mathrm{kg} / \mathrm{ha} \quad(512.0 \quad \mathrm{~g}) \quad$ whereas significantly lowest value of this parameter $(294.07 \mathrm{~g})$ was recorded with the treatment Fym @20 t/ha whereas significantly highest knol-khol yield (413.62 q/ha) was recorded with the treatment NPK(75:50:40)+5.0 Fym t/ha and significantly lowest knol-khol yield $(195.65 \mathrm{q} / \mathrm{ha})$ was recorded with the treatment Fym @20 t/ha.

Experiment results of Kumar et al., (2013) revealed that significantly highest yield of Cole crop (Brassica oleracea var.italica) was recorded with treatment $50 \mathrm{~kg} \mathrm{~N}$ through Vermicompost +150:100:100 kg NPK /ha through in organics whereas the lowest Cole crop yield was recorded with treatment $25 \mathrm{~kg}$ $\mathrm{N}$ through FYM +75:50:50kg NPK through inorganics. Kumar et al., (2013) in their studies on effect of integrated nutrient management on Cole crop (Brassica oleracea var. botrytis) observed that the significantly highest yield of Cole crop was recorded with the treatment 1/2 NPK+ Vermicompost @2.5 t/ha whereas lowest yield of Cole crop was recorded with the treatment recommended dose of NPK/ha(120:80:60 kg/ha)Shree et al., (2014) observed that the highest yield of Cole crop (Brassica Oleracea Var. Botrytis) was recorded with the treatment recommended 
dose of N: P: K @ 120:80:80 kg/ha whereas significantly lowest yield was recorded with treatment $1 / 2 \quad \mathrm{NPK}+$ Vermicompost @ 4t/ha.Mishra et al., (2014) conducted field experiment at college of Agriculture, Orissa under tropical climate zone to study the effect of integrated nutrient management on yield, quality and economics of knol-khol (Brassica oleracea L. Cv. Gongylodes) and observed that the significantly highest yield of Cole crop (348.2 q/ha) was recorded with the treatment $100 \% \mathrm{NPK}+\mathrm{VC}$ which was found statistically at par with the yield of Knol-khol with the treatment $100 \%$ NPK+ FYM whereas treatment (100\% NPK) recorded significantly lowest knol-khol yield (266.1 q/ha) respectively.

Srichandan et al., (2015) observed that the highest average yield of Cole crop (Brassica Oleracea Var. Italica) was recorded with the treatment $100 \% \mathrm{NPK}+100 \% \mathrm{VC}$ which was found statistically at par with the treatment $100 \% \mathrm{NPK}+50 \%$ VC+50 \% FYM whereas significantly lowest yield of Cole crop was recorded with the treatment $100 \%$ NPK Chaudhary et al., (2015) in their study on effect of integrated nutrient management on yield of Cole crop (Brassica Oleracea Var. Italica) under mid hill Gujarat conditions observed that significantly highest yield (t/ha) of Cole crop was recorded with the treatment $100 \%$ RDN +Vermicompost @ 10 t/ha which was found statistically at par with treatment $100 \%$ RDN +FYM @20 t/ha in Cole crop yield whereas significantly lowest Cole crop yield was recorded with the treatment $75 \%$ RDN + FYM @10 t/ha.

Tekasangla et al., (2015) while working on the effect of integrated nutrient management on the Cole crop (Brassica oleracea var. botrytis L.) on the sandy loam soil observed that among the different treatments highest Cole crop yield (t/ha) was recorded with the treatment $100 \% \mathrm{NPK} \quad(120: 60: 60 \mathrm{~kg} / \mathrm{ha})$ whereas lowest Cole crop yield (t/ha) was recorded with the treatment FYM@30 t/ha. Devi et al., (2017) conducted field experiment at Department of Horticulture, college of Agricultur, Jobner to study the influence of organic fertilizers on yield and quality of (Brassica oleracea var. capitata) and observed that among the different treatments significantly highest Cole crop yield(q/ha) was recorded with the treatment VC @8.5 t/ha which was found statistically at par with the yield recorded with the treatment FYM @2/3 i.e., $16.5 \mathrm{t} / \mathrm{ha}+\mathrm{VC} @ 1 / 3$ i.e., $2.8 \mathrm{t} / \mathrm{ha}$ whereas significantly lowest yield was recorded with the treatment FYM @25 t/ha. Kumar et al., (2017) while studying the comparative performance of inorganic and organic fertilizers on yield of Cole crop (Brassica Oleracea var Italica) observed that significantly highest Cole crop yield was recorded with the treatment $\mathrm{RDF}(50 \%)+\mathrm{FYM}$ $(25 \%)+\mathrm{VC}(25 \%)$ whereas significantly lowest Cole crop yield was recorded with the treatment FYM@20.0/ha.

Studies conducted by Kumar et al., (2017) at University of Agriculture Sciences, Dharwad on the effect of integrated nutrient management for protected cultivation of broccoli (Brassica oleracea var. italica) revealed that the among the different treatments significantly highest Cole crop yield was recorded with the treatment $100 \%$ RDF + FYM (Control) which was found statistically at par with the treatment $75 \%$ $\mathrm{RDF}+\mathrm{FYM}$ and $\mathrm{VC}(1: 1)$ equivalent to $25 \%$ RDN whereas significantly lowest Cole crop yield was recorded with the treatment $75 \%$ $\mathrm{RDF}+\mathrm{FYM}$ equivalent to $25 \% \mathrm{RDN}$.

Lodhi et al., (2017) conducted field experiment at the vegetable research field, Sam Higginbottom Institute of Agriculture, Technology and Sciences, Allahabad to study the effect of inorganic and organic fertilizers on yield and economics of Cole crop 
(Brassica oleracea var. italica) and revealed that the significant difference in yield of Cole crop among the different treatments. The highest yield ( $\mathrm{t} / \mathrm{ha}$ ) of the Cole crop was recorded with the treatment $50 \% \mathrm{RDN}+25 \%$ $\mathrm{FYM}+25 \% \mathrm{VC}$ which was found statistically at par with the treatment $50 \% \mathrm{RDN}+50 \%$ $\mathrm{VC}$ whereas the lowest Cole crop yield (t/ha) was recorded with the treatment FYM @ 20 t/ha. Studies conducted by Ram et al., (2017) to study the effect of organic and inorganic on yield of Cole crop (Brassica oleracea var.italica) and observed non-significant difference in yield $(q / h a)$ of the Cole crop. The highest yield ( $q / h a)$ was recorded with the treatment 75\%NP+VC@2.5t/ha followed by $50 \% \mathrm{NP}+\mathrm{VC} @ 2.5 \mathrm{t} / \mathrm{ha}$ whereas lowest Cole crop yield was recorded with the treatment (RDF $125 \mathrm{~N}: 110 \mathrm{P}: 50 \mathrm{~K} \quad \mathrm{~kg} / \mathrm{ha}$ ) +FYM@20 t/ha.

Effect of differential substitution of nutrients through organics on quality of knol- khol

Dalal et al., (2010) conducted field experiment at Horticulture Nursery, college of Agriculture, Gwalior (M.P) and observed that significantly highest Vitamin C (mg/100g) content was recorded with the treatment 50 $\% \mathrm{~N}$ (Urea) $+50 \% \mathrm{~N}$ VC which was found statistically at par with the treatment $75 \% \mathrm{~N}$ (Urea) $+25 \% \mathrm{~N}(\mathrm{VC}), 50 \% \mathrm{~N}($ Urea $)+50 \%$ $\mathrm{N}(\mathrm{FYM})$ in Vitamin C $(\mathrm{mg} / 100 \mathrm{~g})$ whereas significantly lowest Vitamin C (mg/100g) was recorded with the treatment $100 \% \mathrm{~N}(\mathrm{FYM})$.

Padamwar and Dakore et al., (2010) conducted an experiment on Farm at Nanded district of Maharashtra to studied the role of Vermicompost in enhancing the role of Vermicompost in enhancing the nutritional value of some Cole crops and assess that significantly highest ascorbic acid in knolkhol (123.3 mg/100g) was recorded with treatment Vermicompost @11.3 t/ha whereas significantly lowest ascorbic acid in knol-khol
92.9 mg/100g was recorded with FYM @11.3 t/ha. Gill et al., (2011) while working on the Cole crop (Brassica oleracea Var Capitata) a observed significant differences in the ascorbic acid content (mg/100 g) and Chlorophyll content $(\mu / g)$ among the treatments. Significantly highest ascorbic acid content $(\mathrm{mg} / 100 \mathrm{~g})$ and Chlorophyll content $(\mu / g)$ was recorded with recommended NPK (125:60:60 kg/ha) whereas the lowest value of these parameter was recorded with treatment Fym @ 40 t/ha.

Chatterjee et al., (2012) while working on the enhancement of head yield and quality of Cole crop (Brassica oleracea) by combining different sources of nutrients and observed that among the different treatments significantly highest Chlorophyll content (SPAD Value) and Vitamin C (mg/100g) was recorded with the treatment $75 \% \mathrm{RDF}+5$ tonnes $\mathrm{VC} /$ ha which was found statistically at par with $75 \%$ RDF+16 tonnes Fym/ha whereas significantly lowest value of Chlorophyll content (SPAD Value) and Vitamin C (mg/100g) was recorded with the treatment 100\% RDF (150N:80P:75 K kg/ha).

Experiment results of Shree et al., (2014) revealed significantly highest ascorbic acid content in(Brassica Oleracea var Botrytis L.) with the treatment 1/2 NPK + FYM @ 5 t/ha +Vermicompost @2 t/ha whereas significantly lowest ascorbic acid content (mg/100 g of Juice) was recorded with treatment 1/2 NPK +Fym @ 10t/ha. (N: P: K120:80:80 kg/ha).Mishra et al., (2014) found non-significant difference among the different treatments for ascorbic acid (mg/100 g) and Chlorophyll content (\%).

The highest ascorbic acid content (47.5 $\mathrm{mg} / 100 \mathrm{~g}$ ) of knol-khol knob was recorded with treatment $100 \mathrm{NPK}+\mathrm{VC}$ whereas highest chlorophyll content $(58.62 \%)$ was recorded with the treatment $100 \%$ NPK+FYM whereas the lowest ascorbic acid content 
(45.4 mg/100g) of knol-khol knob was recorded with the treatment (100\% NPK) whereas the lowest chlorophyll content (52.48 $\%)$ at harvest of knol-khol was recorded with the treatment $100 \%$ NPK +VC. Kumar and Devi et al., (2016) in their studies observed that significantly highest ascorbic acid content (mg/100 g) of Cole crop (Brassica oleracea var. Botyrtis) was recorded with recommended dose of chemical fertilizer + FYM whereas significantly lowest value of ascorbic acid (mg/100g) in Cole crop was recorded with the treatment organic manure (20 t/ha).

Devi et al., (2017) conducted field experiment on loamy sand soil at department of Horticulture, College of Agriculture, Jobner to assess the effect of organic fertilizers on yield and quality of Cole crop (Brassica oleracea var. capitata) and observed that among the different treatments significantly highest ascorbic acid content (mg/100g) in Cole crop was recorded with the treatment VC @ $8.5 \mathrm{t} /$ ha which was found statistically at par with the ascorbic acid $(\mathrm{mg} / 100 \mathrm{~g})$ recorded for treatment FYM @2/3 i.e., 16.5t/ha +VC $1 / 3 @ 2.8 \mathrm{t} / \mathrm{ha}$ whereas significantly lowest ascorbic acid (mg/100g) was recorded with the treatment FYM @25t/ha. Kumar et al., (2017) in their studies observed significant difference in SPAD reading of Cole crop (Brassica oleracea var. italica).

Significantly highest SPAD reading was recorded with the treatment $100 \%$ RDF +FYM (control) whereas significantly lowest SPAD reading was recorded with the treatment $75 \% \mathrm{RDF}+\mathrm{FYM}$ equivalent to $25 \%$ RDN. Tekasangla et al., (2015) in their studies observed that among the different treatments significantly highest ascorbic acid $(\mathrm{mg} / 100 \mathrm{~g})$ in Cole crop was recorded with the treatment $100 \% \mathrm{NPK}(120: 60: 60 \mathrm{~kg} / \mathrm{ha})$ whereas significantly lowest ascorbic acid (mg/100g) was recorded with the treatment Vermicompost @10/ha.
Effect of differential substitution of nutrients through organics on soil properties of knol-khol

Study conducted by Bhanu shalini et al., (2002) on red sandy clay soil of Dharwad soil reported that the highest available nitrogen $(201.1 \mathrm{~kg} / \mathrm{ha})$ in soil was recorded with the treatment $75 \% \mathrm{~N}$ (Urea)+25 \% $\mathrm{N}$ (VC) whereas the lowest available $\mathrm{N}(192.8 \mathrm{~kg} / \mathrm{ha})$ in soil was recorded with the treatment RDF (150:100:125 kg/ha) which was found at par with the treatment $50 \% \mathrm{~N}$ (Urea)+ $50 \%$ $\mathrm{N}($ Fym $)$ with $(193.2 \mathrm{~kg} / \mathrm{ha})$ available soil $\mathrm{N}$. Kanwar and Paliyal (2005) while working on the effect of integrated nutrient management on growth and yield of (Brassica oleracea var capitata) and revealed non-significant difference in $\mathrm{pH}$ among the different integrated nutrient treatments whereas significant difference was recorded in soil among the different treatments for organic carbon (\%), available NPK after the harvesting of the Cole crop. Significantly highest value of $\mathrm{OC}(\%)$ during the first year was recorded with the treatment VC @25 t/ha +100 \% NPK whereas significantly highest value of OC (\%) during the second year was recorded with the soil having treatment FYM @25 t/ha whereas significantly lowest value of OC (\%) was recorded with the treatment FYM @ 25t/ha whereas the highest value of average available N,P and $\mathrm{K}$ in soil for both the years was recorded with the treatment VC @ 25 t/ha $+100 \%$ NPK whereas the lowest average value of available $\mathrm{N}$ in soil was recorded with the treatment $100 \%$ NPK whereas the lowest value of available $P$ and $K$ in soil was recorded with the treatment Vermicompost @ 25 t/ha. Sur et al., (2010) conducted field experiment at new alluvial soil of west Bengal to study the effect of integrated nutrient management on soil fertility and organic carbon in Cole crop (Brassica oleracea var. capitata) growing soil and observed that the 
significantly highest $\mathrm{pH}$ value after the harvest of Cole crop was recorded with the treatment NPK(150:26:66 $\mathrm{kg} / \mathrm{ha})$ only whereas the lowest value of $\mathrm{pH}$ was recorded with NPK (150:26:66 kg/ha) +Organic manure@8 tonnes/ha.

Significantly highest value of OC (\%) was recorded with the treatment organic manure@10 t/ha which was found statistically at par with the treatment NPK (150:26:66 $\mathrm{kg} / \mathrm{ha}$ ) +Organic manure @ 4 tonnes/ha whereas significantly lowest value of OC (\%) was recorded with the treatment NPK (150:26:66 kg/ha) +Organic manure @8tonnes/ha.

Among the different treatments the highest value of Available NPK in soil after the harvest of the Cole crop was recorded with the treatment NPK (150:26:66 kg/ha) +Organic manure@8tonnes/ha whereas the lowest value of Available $\mathrm{N}$ and $\mathrm{P}$ was recorded with the treatment NPK whereas the lowest value of Available $\mathrm{K}$ was recorded with the treatment organic manure @ 10 t/ha.

Tekasangla et al., (2015) in their studies on effect of integrated nutrient management on the Cole crop (Brassica oleracea var. botrytis L.) and observed non-significant difference in soil $\mathrm{pH}$ and organic carbon (\%) whereas significant difference was recorded in available $\mathrm{N}$, available $\mathrm{P}$ and available $\mathrm{K}$ $(\mathrm{kg} / \mathrm{ha})$ in soil after the harvest of the crop.

Among the different treatments significantly highest value of available $\mathrm{N}$ (kg/ha) was recorded with the treatment $100 \%$ NPK (120:60:60 kg/ha) whereas significantly highest value of available $\mathrm{P}$ and available $\mathrm{K}$ in soil was recorded with the treatment $50 \%$ NPK $+50 \%$ Vermicompost.

Kumar et al., (2017) in their studies observed significant difference in soil available $\mathrm{N}, \mathrm{P}$ and $\mathrm{K}$ after the harvest of Cole crop (Brassica
Oleracea var Italica).Significantly highest available $\mathrm{N}, \mathrm{P}$ and $\mathrm{K}(\mathrm{kg} / \mathrm{ha})$ was recorded with the treatment RDF (50\%)+FYM (50\%)+ VC(50\%) whereas the lowest available N,P was recorded with the treatment (FYM@20 t/ha) whereas lowest available $\mathrm{K}$ was recorded with the treatment (VC 5.0t/ha).

\section{Effect of differential substitution of nutrients through organics on nutrient uptake of knol-khol}

Study conducted by Kanwar and Paliyal (2005) reported that the significantly highest uptake of $\mathrm{N}$ in (Brassica Oleracea var Capitata) was recorded with the treatment Fym @25 t/ha +100\% NPK whereas the highest value of $\mathrm{P}$ and $\mathrm{K}$ uptake was recorded with the treatment VC @ $25 \mathrm{t} / \mathrm{ha}+100 \%$ NPK whereas significantly lowest value of FYM @25 t/ha. Patel et al., (2011) in their studies on effect of INM on nutrient uptake of Cole crop (Brassica Oleracea var Botrytis L.) observed that among the different treatments significantly highest NPK uptake $(\mathrm{kg} / \mathrm{ha})$ in Cole crop was recorded with the treatment VC @ 4t/ha which was found statistically at par with treatment VC @ $3 \mathrm{t} / \mathrm{ha}$ whereas the lowest NPK uptake was recorded with the treatment Fym @20 t/ha.

Kumar and Devi (2016) conducted field experiment at experimental farm of CSK Himachal Pradesh, Bajaura on soil with $\mathrm{pH}$ 6.7 and organic carbon $(0.78 \%)$ to study the effect of inorganic amendments on mineral composition and quality of Cole crop (Brassica oleracae var. Botrytis) and observed that significantly highest nutrient uptake viz., nitrogen, phosphorus and potassium uptake in (Brassica oleracea var. botrytis) was recorded with the treatment recommended dose of fertilizer N:P:K @ 100:75:55 + Fym whereas significantly lowest nutrient uptake in Cole crop was recorded with the treatment organic manure (20 t/ha). 
Effect of differential substitution of nutrients through organics on economics of knol-khol

Patel et al., (2011) conducted field experiment on soil with neutral $\mathrm{pH}$ to study the effect of integrated nutrient management on the economics of Cole crop (Brassica oleracea L. var. Botrytis) and observed that among the different treatments the highest net realization (Rs/ha) and BCR was recorded with the treatment $3 \mathrm{t} \mathrm{VC} / \mathrm{ha}$ whereas lowest net realization (Rs/ha) and BCR was recorded with the treatment $20 \mathrm{t} \mathrm{FYM/ha.} \mathrm{Studies}$ conducted by Mishra et al., (2014) at University of Agriculture and Technology, Bhubaneswar on the effect of integrated nutrient management on yield, quality and economics of Knol-khol (Brassica oleracea L. cv. gongylodes) observed that the among the different treatments the highest cost of cultivation (66940Rs/ha), net returns (139292Rs/ha) of knol-khol was recorded with the treatment $100 \% \mathrm{NPK}+\mathrm{VC}$ whereas the highest $\mathrm{B}$ : $\mathrm{C}$ ratio was recorded with the treatment $100 \% \mathrm{NPK}+\mathrm{FYM}$. The lowest value of Cost of cultivation (51240 Rs/ha), net returns (106440 Rs/ha) and B: C ratio (2:1) for knol-khol was recorded with the treatment $100 \%$ NPK. Srichandan et al., (2015) while studying the influenced of organic and in organic nutrients on yield of Cole crop (Brassica oleracea var Italica) observed that the among the different treatments the highest cost of cultivation (Rs/ha), Gross return (Rs/ha) and Net returns (Rs/ha) was recorded with the treatment $100 \% \mathrm{NPK}+100 \% \mathrm{VC}$ whereas minimum cost of cultivation (Rs/ha), Gross return (Rs/ha) and Net returns (Rs/ha) was recorded with the treatment 100\% NPK. Lodhi et al., 2017 while working on the effect of organic and inorganic fertilizers on the yield and economics of Cole crop(Brassica Oleracea var Italica) observed that the among the different treatments the highest cost of cultivation (Rs/ha) of Cole crop was recorded with the treatment Fym @20t/ha, the highest Gross returns (Rs/ha) was recorded with the treatment $50 \% \mathrm{RDN}+25 \% \mathrm{FYM}+25 \% \mathrm{VC}$ whereas the highest net returns and $\mathrm{B}$ : $\mathrm{C}$ ratio was recorded with the treatment RDF (120:80:80 NPK kg/ha) whereas minimum cost of cultivation (Rs/ha) of Cole crop was recorded with the treatment RDF (120:80:80 NPK $\mathrm{kg} / \mathrm{ha}$ ), the minimum Gross returns (Rs/ha), net returns and B: C ratio was recorded with the treatment FYM @ 20 t/ha. Ram et al., (2017) while working on Cole crop (Brassica oleracea L. var. Capitata) observed that among the different treatments the highest cost of cultivation (Rs/ha) of Cole crop was recorded with the treatment $75 \% \mathrm{NP}$ +VC@2.5 t/ha whereas highest net returns (Rs/ha) and B: C ratio was recorded with the treatment RDF (125 N:110P:50 K kg/ha)+ FYM @ 20 t/ha whereas lowest Cost of cultivation (Rs/ha) was recorded with the treatment RDF (125 N:110P:50 K kg/ha)+ FYM @ 20 t/ha whereas lowest net returns (Rs/ha) and B: C ratio was recorded with the treatment 50\%NP+VC @2.5 t/ha.

\section{References}

Atiyeh R M, Lee S S, Edwards CA, Arancon N Q and Metzger J.2002. The influence of humic acid derived from earth worm processed organic waste on plant growth. Bioresource Technology.84:714.

Bhanu shalini, S., Channal, H.T., Hebsur, N.S., Dharmatti, P.R. and Sarangamath,P.A.2002.Effect of nitrogen management on yield of knolkhol and population of Azospirillium in Vertisol. Karnataka Journal of Agricultural Sciences. 15(1):151-153.

Bose, T.K. (1986). Vegetables Crops in India. Bhubani Mitra, Naya Prakashan, Kolkata Chatterjee, R., Bandhopadhyay, S. and Jana, J.C.2014. Organic 
amendments influencing growth, head yield and nitrogen use efficiency in cabbage (Brassica oleracea var.capitata L.). American International Journal of Research in Formal, Applied and Natural Sciences. 5(1):90-95.

Chatterjee,R., Jana, J.C. and Paul, P.K.2012. Enhancement of head yield and quality of cabbage (Brassica oleracea) by combining different sources of nutrients. Indian Journal of Agricultural Sciences, 82(4):324-328.

Chaudhary, M.M., Bhanvadia, A.S. and Parmar, P.N. Effect of integrated nutrient management on growth, yield attributes and yield of Cabbage (Brassica oleracea var. Capitata L.). Trends in BioSciences. 8(8):2164-2168.

Chaurasia, S.N.S, Singh, R. and Rai, M.2009. Effect of integrated nutrient management and spacing on yield, Quality and economics of Broccoli (Brassica oleracea var.italica). Vegetable Science, 36(1):51-54.

Choudhary, B. (1967). Vegetable, National Book Trust of India. New Delhi.72-73.

Cosic T., Vinterhalter B., Mitic N.,Cingel A., Savic J., Ninkovic $S$ and Bohanec B.(2013). In Vitro plant regeneration from immature zygotic embryos and repetitive somatic embryogenesis in kohlrabi (Brassica oleracea var. gongylodes). In vitro Cell Dev Biol Plant ; 49: 294-303.

Curry, J.P. (1987). The invertebrate fauna of grassland and its influence on productivity. The composition of the fauna. Grass For. Sci., 42:103-120.

Dalal, V.V., Bharadiya, P.S. and Aghav, V.D. 2010.Effect of organic and inorganic sources of nitrogen on quality of cabbage (Brassica oleracea var. capitata L.). International Journal of Agricultural Sciences. 6(2): 599-601.

Dalal, V,V., Bharadiya, P.S. and Aghav, V.D. 2010. Effect of organic and inorganic sources of nitrogen on growth and yield of cabbage (Brassica oleracea var. capitata L.). The Asian Journal of Horticulture, 5(2): 291-293.

Devi, K.B and Singh, N.I.2012. Yield response of cabbage (Brassica oleracea var.capitata) cv. Pride of India to varying levels of chemical fertilizers and Vermicompost. Journal of Agriculture and Veterinary Science. 1(3):Pp8-11.

Devi,S., Choudhary, M., Jat, P.K., Singh, S.P. and Rolaniya, M.K. 2017. Influenced of organic and biofertilizers on yield and quality of cabbage (Brassica oleracea var. capitata). International Journal of Chemical studies, 5(4):818-820.

Ghosh, C., Mandal, J. and Chattopadhyay, G.N. 2009. Effect of Vermicompost on growth and yield of cabbage. International Conference on Horticulture, $\mathrm{Pp}-1758-1759$.

Harbaum B, Hubbermann EM, Wolff C, Herges R, Zhu Z and Schwarz K (2007) Identification of flavonoids and hydroxyl cinnamic acids in pak choi varieties (Brassica campestris L. ssp. chinensis var. communis) by HPLCESI-MSn and NMR and their quantification by HPLC-DAD. J Agric Food Chem; 55: 8251-8260.

Kanwar, K. and Paliyal, S.S. 2005.Effect of integrated nutrient management on growth and yield of cabbage. Himachal Journal of Agricultural Research, 31(1): 15-20.

Kumar, G. and Biradar, M.S.2017. Integrated nutrient management studies for protected cultivation of broccoli (Brassica oleracea var. italica L.). International Journal of Chemical Studies, 5(4): 225-227.

Kumar, M., Das, B., Prasad, K.K. and Kumar.P.2013.Effect of integrated nutrient management on growth and yield of Broccoli (Brassica oleracea 
var.italica) under Jharkhand conditions. Vegetable science. 40(1): 117-120.

Kumar,M., Kumar, S., Sharma, J.P., Kohli.A. and Bhat. A. 2008. Effect of integrated nutrient management practices in rain fed knol-khol (Brassica oleracea var gongyloides) growing under intermediate zone of Jammu. Environment and Ecology, 26(4B): 2119-2122.

Kumar,P.,Bhardwaj,M.L.,Kumar,D.,Kumar,R .,Tripathi,D.,Thakur,K.S.,Bharat,N.,Gau tam,N.,Kumar,S. and Dogra, B. 2017. Comparative performance of organic and inorganic fertilizers on plant growth, head yield, soil health and severity of black rot in sprouting broccoli cv Green head. International Journal of Farm Sciences, 7(1):69-76.

Kumar, S., Singh, J.P., Rajbeer, Ram, N., Mohan, B., Kaushik, H. and Kumar, D. 2013.Influence of integrated nutrient management on growth and yield of cauliflower (Brassica oleracea var. Botrytis L.) cv.NHB-1012, International Journal of Agricultural Sciences, 9(2):747-749.

Kumar, V. and Devi, S. 2016. Effect of Biofertilizers and inorganic amendments on Mineral composition and quality of Brassica oleracea. Asian Journal of Advance Basic Sciences. 4(2):20-26.

Lodhi, P., Singh, D. and Tiwari, A. 2017. Effect of inorganic and organic fertilizers on yield and economics of Broccoli (Brassica oleracea var. italica). International journal of current Microbiology and applied sciences. 6(8): 562-566.

Mishra, P.P., Das, A.K. and Mishra, N. Effect of Integrated nutrient management on yield, quality and economics of Knolkhol (Brassica Oleracea L. cv. Gongylodes).The Asian Journal of Horticulture, 9(2): 382-385.

Nagavallemma KP, Wani SP, Lacroix S,
Padmaja VV, Vineela C,Babu Rao M, Sahrawat KL (2004). Vermicomposting: Recycling wastes into valuable organic fertilizer. Global theme on Agroecosystems Report no.8 Patancheru 502 324, Andhra Pradesh, India: International Crops Research Institute for the Semi Arid Tropics,p-20.

Nanjappa, H.P., Ramchanrappa, B.K and Mallikarjuna, B.O. 2001. Effect of integrated nutrient management on yield and nutrient balance in Maize. Indian Journal of Agronomy. 46(4):668-701.

Padamwar. S.B and Dakore H.G. 2010. Role of Vermicompost in enhancing nutritional value of some Cole crops. International Journal of Plant sciences. 5(1): 397-398.

Patel, K.K., Patel, B.A., Jadav, N.J., Patel, J.C. and Panchal, D.B. 2011. Influence of integrated nutrient management on curd yield, quality and nutrient uptake and economics of cauliflower (Brassica oleracea var. Botrytis L.) under middle Gujarat. Advance Research Journal of Crop Improvement. 2(2): 193-196.

Ram, P.Y., Sharma, A.K., Kaushal, R., Singh, M.K. and Maurya, A.K. 2017. Effect of organic, inorganic and plant growth promoting rhizobacteria (PGPR) on growth and yield of cabbage in mid hills of Himachal Pradesh and study of their economics. Vegetos-An International Journal of Plant Research,30(Special), Pp499-504

Ramesh P., Panwar N.R., Singh A.B., Ramana S., Yadav S.K. and Rao A.S. (2010). Status of Organic Farming in India. Current Science 98 (9): 11901194.

Sallaku G, Babaj I, Kaciu S,Balliu A (2009).The influence of Vermicompost on plant growth characteristics of cucumber (Cucumis sativus L.) seedling under saline condition. J. Food Agric. Environ., 7(3-4):869-872. 
Savic, S. 2012. An Agricultural pollutant: chemical fertilizer, International Journal of Environment Science and Development. 3(1):77-80.

Sharma A., Parmar D.K., Kumar P., Singh Y. and Sharma R.P. (2008). Azotobacter soil amendment integrated with cow manure reduces need for NPK fertilizers in sprouting broccoli. International Journal of Vegetable Science, 14(3): 273-285.

Sharma, J.P., Rattan, P. and Kumar, S. 2012. Response of vegetable crops to use of integrated nutrient management practices. Journal of food and Agriculture Science. 2(1):15-19.

Shree, S., Singh, V.K. and Kumar, R. 2014. Effect of integrated nutrient management on yield and quality of cauliflower (Brassica Oleracea var Botrytis L.), The Bioscan. 9(3):10531058.

Singh R, Sarma R, Satyendra K, Gupta R, Patil R (2008). Vermicompost substitution influences growth, physiological disorders, fruit yield and quality of strawberry (Fragaria $\mathrm{x}$ ananassa (Duch.) Biorecour. Technol., 99: 8502-8511.

Singh, S.P. (1989). Production technology of vegetable crops. Agricultural Research Communication Centre, Karnal (Haryana).

Singh, A., Singh, T. and Singh, B.N. 2009. Influence of integrated nutrient management on growth, yield and economics of Cauliflower (Brassica oleracea L. Var Botrytis), Vegetable Science, 36(3): 340-343.

Srichandan, S., Mangaraj, A.K., Behera, K.K., Panda, D., Das, A.K. and Rout, M. 2015. Growth, Yield and Economics of Broccoli (Brassica oleracea var. Italica) as influenced by organic and inorganic nutrients. International Journal of Agriculture, Environment and Biotechnology. 8(4): 965-970.

Sur, P., Mandal, M. and Das, D.K. 2010 .Effect of integrated nutrient management on soil fertility and organic carbon in cabbage (Brassica oleracea var capitata) growing soils. Indian Journal of Agricultural Sciences, 80(8): 38-41.

Terry P., Giovannucci E., Michels K.B., Bergkvist. L., Hansen H, Holmberg L and Wolk A (2001) Fruit and vegetables, dietary fiber, and risk of colorectal cancer. J Natl Cancer Inst; 93: 525-533.

\section{How to cite this article:}

Banotra, M., B.C. Sharma, A. Kumar, A. Samanta, B. Nandan, I.A. Shah, A. Verma, R. Kumar and Namgial, T. 2017. Critical Review - Impact of Differential Substitution of Organics for in Organics on Growth, Yield, Quality, Economics and Soil Properties of Cole Crop (Brassica oleracea var gonylodes L.). Int.J.Curr.Microbiol.App.Sci. 6(11): 3180-3194.

doi: https://doi.org/10.20546/ijcmas.2017.611.373 